\title{
Prothrombin Complex Concentrates in Life-Threatening Bleeding
}

\author{
Mustafa Burak Sayhan ${ }^{1}$, Ömer Salt ${ }^{1}$, Ahmet Muzaffer Demir ${ }^{2}$ \\ ${ }^{1}$ Department of Emergency Medicine, Trakya University School of Medicine, Edirne, Turkey \\ ${ }^{2}$ Department of Internal Medicine /Hematology, Trakya University University School of Medicine, Edirne, Turkey
}

To the Editor,

We recently read with special interest the manuscript entitled "Spontaneous Isolated Pericardial Tamponade Associated with Warfarin". The authors presented the treatment of a rare life-threatening condition, cardiac tamponade related to Vitamin K antagonist (VKA) use (1).

In a clinical guideline entitled "The management of VKA treatment-related bleedings", it is stated that hemopericardium is a life-threatening condition, like intracranial hemorrhage and gastrointestinal bleeding (2). If early diagnosis and appropriate treatment is delayed, it can progress rapidly and becomes a life-threatening condition (1). The most important factor leading to the high mortality rate is not reversing the anticoagulation rapidly enough (3).

Traditionally, vitamin $\mathrm{K}$ and fresh frozen plasma (FFP) preparations are used in the treatment of these life threatening side effects of VKA use. Additionally, prothrombin complex concentrates (PCC) have recently been used effectively with these preparations, as highlighted in the guidelines (4).

We want to emphasize in our letter that in the treatment of fatal bleeds due to VKA use, PCCs could be used effectively and successfully in addition to conventional treatment methods.

Vitamin $\mathrm{K}$ requires at least 4 hours to initiate the treatment effect and requires almost 24 hours for maximum effect. This causes a delay in the therapeutic intervention, as well as causing delay in halting the bleeding $(2,3)$.

In a guideline about management of the risk situations associated with the use of VKA, it is emphasized that the International Normalized Ratio (INR) must be reduced $\leq 1.5$ as soon as possible and that PCC is the most appropriate preparation for such clinical conditions (grade C, level 3). It is also highlighted that the application of PCC reverses the side effects of VKA quickly, compared to the use of vitamin K alone. If PCC and vitamin $\mathrm{K}$ are used together, the INR value decreases to 1.2-2 within 10 minutes in approximately $79-100 \%$ of patients (2).
It is recommended that vitamin $\mathrm{K}$ should be used alone in those patients with bleeding due to VKA as they can wait for 18-24 hours before requiring therapeutic intervention. However, if the patient requires urgent intervention, $\mathrm{PCC}$ and vitamin $\mathrm{K}$ must be applied together (grade $\mathrm{C}$, level 3). Infused clotting factors of PCC have half-lives similar to endogenous clotting factors. Therefore, vitamin $\mathrm{K}$ should be given simultaneously with PCC to sustain the reversal effect (4).

In the study of Sarode et al. (5), hemostatic efficacy of PCC and FFP was compared in patients with life-threatening bleeding due to VKA use. The hemostatic effectiveness of the PCC was found to be $72 \%$, while it was $65 \%$ for FFP. The target INR values were reached in $62 \%$ of the PCC group, while only $9.6 \%$ of the FFP group reached the target values.

If FFP is used alone, a large volume will be required. It is also necessary to know the patient's blood group and there is a risk of viral infection and transfusion-related lung injury. Because of the risk of transfusion-related circulatory overload in patients with chronic renal failure and congestive heart failure, FFP must be used carefully (4). In contrast to FFP, PCC is used in the form of a powder and is therefore always ready to use. This is a significant advantage in emergency conditions.

The factor concentrate in PCC is much higher than FFP (3). Therefore, high doses of PCC could cause thrombosis. In order to prevent this situation, some PCCs contain Protein C and $\mathrm{S}$, while others contain heparin (4).

In conclusion, PCC use should be avoided in all patients with VKA-induced high INR values and must only be considered in patients who require emergency surgery for severe, life-threatening bleeding.

\section{Ethics Committee Approval: N/A.}

Informed Consent: N/A.

Peer-review: Externally peer-reviewed.

Address for Correspondence: Dr. Mustafa Burak Sayhan, Department of Emergency Department, Trakya University School of Medicine, Edirne, Turkey

Phone: +905327000095 e-mail: drsayhan2440@yahoo.com

Received: 2 December 2015 Accepted: 19 February $2016 \quad$ DOI: 10.5152/balkanmedj.2016.151625

Available at www.balkanmedicaljournal.org

Cite this article as:

Sayhan MB, Salt Ö, Demir AM. Prothrombin complex concentrates in life-threatening bleeding. Balkan Med J 2016;33:712-3. 
Author contributions: Concept - M.B.S., O.S., A.M.D.; Design - M.B.S., O.S., Supervision - A.M.D.; Resource - M.B.S., O.S., Materials - M.B.S., O.S., Data Collection and/or Processing - M.B.S., O.S., A.M.D.; Analysis and/or Interpretation - A.M.D.; Literature Search - M.B.S., O.S., Writing - M.B.S., O.S., A.M.D.; Critical Reviews - M.B.S., O.S., A.M.D.

Conflict of Interest: No conflict of interest was declared by the authors.

Financial Disclosure: The authors declared that this study has received no financial support.

\section{REFERENCES}

1. Akgedik R, Günaydın ZY, Kızılırmak D, Gürel YE. Spontaneous isolated pericardial tamponade associated with warfarin. Balkan Med J 2015;32:135-6. [CrossRef]
2. Pernod G, Godiér A, Gozalo C, Tremey B, Sié P. French clinical practice guidelines on the management of patients on vitamin $\mathrm{K}$ antagonists in at-risk situations (overdose, risk of bleeding, and active bleeding). Thromb Res 2010;126:167-74. [CrossRef]

3. Wiedermann CJ, Stockner I. Warfarin-induced bleeding complications-clinical presentation and therapeutic options. Thromb Res 2008;122(Suppl 2):13-8. [CrossRef]

4. Tran HA, Chunilal SD, Harper PL, Tran H, Wood EM, Gallus AS. An update of consensus guidelines for warfarin reversal. Med J Aust 2013;198:198-9. [CrossRef]

5. Sarode R, Milling TJ, Refaai MA, Mangione A, Schneider A, Durn BL, et al. Efficacy and safety of a 4-factor prothrombin complex concentrate in patients on vitamin $\mathrm{K}$ antagonists presenting with major bleeding: a randomized, plasma-controlled, phase IIIb study. Circulation 2013;128:1234-43. [CrossRef] 